\title{
Zircon behavior in the metasedimentary rock during continental collision: constraints from felsic granulites in the Bohemian massif
}

\author{
GUANG YANG, REN-Xu CHEN*, YoNG-FEI ZHENG
}

CAS Key Laboratory of CRUST-Mantle Materials AND ENVIRONMENTS, SCHOOL OF EARTH AND SPACE SCIENCES, UNIVERSITY OF SCIENCE AND TECHNOLOGY OF CHINA, HeFEI 230026, CHINA CHENRX@USTC.EDU.CN

Different types of zircons have been recognized in UHP metamorphic rocks during continental collision, however, it is still unclear about their relationship with metamorphic reactions and anatexis. A combined study of petrology and geochemistry for the felsic granulites from the Bohemian Massif was carried out to link zircon growth to metamorphism and anatexis, and further to provide contraints on zircon behavior during the continental collision. During the prograde evolution from HP amphibolite-facies to UHP eclogite-facies, biotite and plagioclase were consumed to form Grt $+\mathrm{Ms}+$ Omp as well as zircon and monazite. During the metamorphic transition from UHP eclogite facies to UHT granulite facies, muscovite underwent dehydration melting to form garnet as well as zircon and monazite. With the gradual disappearance of muscovite, more omphacite was involved in the peritectic reaction and contributed to continuous growth of zircon and monazite. During the UHT granulite facies metamorphism, garnet was consumed and plagioclase was formed. Zircon in this stage exhibits a significantly negative correlation between HREE contents and $\mathrm{Eu}$ negative anomalies. As the degree of partial melting increases, the previous zircon and monazite were dissolved into the anatectic melt. Finally, in the stage of decompressional cooling, biotite, feldspar and quartz as well as zircon and monazite were crystallized from the evolved anatectic melt. Zircon and monazite formed at these different stages have different trace element compositions, which are mainly controlled by metamorphic and peritectic reactions as well as paragenetic mineral assemblages. Zircon in the metasedimentary rock can grow at the different stages during the collisional orogeny, and its dissolution and growth mainly depend on anatectic conditions, anatectic extent, the property of peritectic reactions, and the stability of Ti-rich minerals. The anatectic melts produced during the metamorphic transition from the UHP eclogite facies to the UHT granulite facies underwent different degrees of fractional crystallization, resulting in the differences in the composition of residual, metamorphic, peritectic and magmatic minerals. 